\title{
Brand Avoidance Motivators Stimulate to Brand Equity in the Mediating Role of Brand Hate: A Case of Smartphone Industry of Pakistan
}

Rizwana Abid* and Aamir Khattak

Department of Management Sciences, Capital University of Science and Technology, Islamabad, Pakistan

\begin{abstract}
This study aims to examine the effect of brand avoidance motivators on brand equity. It also probes the mediating effect of brand hate among brand avoidance motivators and brand equity. In order to empirically study the above relationship the questionnaire was presently administered to the sample of 400 smartphone users. The 270 questionnaire were returned back. The received data was subjected to a number of statistical analyses. The finding proposed that brand avoidance motivators i.e., unmet expectations, symbolic congruence and ideological incapability have positive impact on brand equity. The brand hate copiously mediates between brand avoidance motivators and brand equity. The findings have number of implications for marketers and mangers in Islamabad regarding brand avoidance. Generally, this thesis contributes knowledge to the emergent field of anti-consumption research by means of a pioneering impression and an integrative understanding of a less explored realm of brand avoidance.
\end{abstract}

Keywords: Brand avoidance motivators; Brand equity; Brand hate

\section{Introduction}

The wide field of brand avoidance and the categorical subject of anti-consumption are increasingly converted into a pertinent and fascinating for mangers, researchers, customers and clients. Mostly consumers try to share their experience regarding different products with friends and family. Best performance can be valuable and raises free give free promotional campaigns for companies. Unluckily, consumers spread bad experiences more frequently as compared to good experiences [1], which may result into negative word-of-mouth for the regarding companies which increases negative brand equity.

Any brand of a company is known as a precious asset and mostly contain affirmative equity, whenever conveys its worth to the corporation or enterprise through aiding endure and enhance cash flow for the investors as well as corporation or business [2]. Though, Keller [3] discuss that when consumers perform positively then brand equity will be high, auspiciously to the brand than an undistinguishable service or product which has deceptively titled. Berry [4] also proposes two types of brand equity exist positive brand equity and negative brand equity. By including the reputation of its inside marketing, two facts are obvious. Primary and foremost is perfect which conveys brands are significant for marketers besides affirmative brand equity is a more valued element of business strength. Subsequent, a negative element about brand equity, though the impression has not been adequately measured. Though, some previous studies appear to agree with the brand equity which signifies the additional worth awarded by the trademark to the product [5].

Now with the change in dynamics consumers' voice their view about services and brands. They should be inspired by their own need of self-expression as well as in search of other consumers' experiences through some brands and services. With the awareness in consumers, mostly consumers' complaint sites are increasing in number and disclose examples of people who have established hate emotions towards brands once loved, or just oppose brands which are not associated with the self. People can choose frequent set of brands within diverse categories, these are fluctuating from technology e.g., PS3 in competition with Xbox 360 to celebrities e.g., Lady Gaga versus Katy Perry. Why we either hate or love some brands differ, however, consumers look to have an view about the brands they select to either love or hate. Or is it that simple? If I love something, does that mean that I hate something else? Is hate the opposite of love? So it is very important for managers to have thoughtful views of what consumers consider about their brand, but not essentially everyone has any view about the brands they are using e.g., brands used out of requisite, such as soap. Consumers have different ratios of brand love and brand hate as "I love Coca Cola" has 7562 votes $(70.79 \%)$, whereas "I love Pepsi" contain only 3121 votes $(29.21 \%)$. A new disreputable conflict is Samsung versus Apple. Similarly to this when think about operating systems, "I love Android" has 8563 votes (60.96\%), whereas "I love Apple iOS" has 5485 votes (39.04\%), however, the battle extended a tie when considering a specific smart phone developed by each of the brands, where "I love Samsung Galaxy" has 5762 votes (51.53\%), while "I love iPhone" got 5419 votes (48.47\%) [6].

Typically consumer behavior research is intensive on ingesting of brands from a positive viewpoint, though, marketing specialists are apprehensive not only about the causes why some brands are being selected but also what reasons anti- consumption of particular brands [7], subsequently negative brand relationships can be harmful to companies possessing these brands [8]. If the causes leading consumers to discard brands are acquainted to companies, enterprises contain a coincidental to stop or alleviate the disapproving results [7], it is considered that consumers may not only stopover consuming an explicit brand nevertheless disseminate negative views of the brand to others.

What are negative attitudes concerning with brands are likely to be distributed by social networks as compared to positive experiences of ingestion [9]. It is also valuable to declare that searching of brand

*Corresponding author: Rizwana Abid, Department of Management Sciences, Capital University of Science and Technology, Islamabad, Pakistan, Tel: +92-514486700-4; E-mail: rizwana.abid20@yahoo.com

Received July 30, 2017; Accepted August 08, 2017; Published August 12, 2017

Citation: Abid R, Khattak A (2017) Brand Avoidance Motivators Stimulate to Brand Equity in the Mediating Role of Brand Hate: A Case of Smartphone Industry of Pakistan. J Account Mark 6: 250. doi: 10.4172/2168-9601.1000250

Copyright: (c) 2017 Abid R, et al. This is an open-access article distributed under the terms of the Creative Commons Attribution License, which permits unrestricted use, distribution, and reproduction in any medium, provided the original author and source are credited. 
avoidance motivators are very vital for all marketing specialists even for competitor, mostly such type this knowledge can be purposefully used for their brands' positioning as an engaging substitute [7]. Brand avoidance is states as a process where consumers intentionally select to discard any product. Dualistic important thoughts remain adjacent to the learning of brand evasion. One is the anti-constellation that encompasses goods which are excluded by customers [10]. Contrasting to it, low prominence on products or brands in the learning of anti-constellations. The other idea that is very similar to brand evasion is the incompetent conventional [11], which has negative evaluation accredited to an aversion of the poor product performance advertisement. Bryson et al. [12] state brand hate as 'a powerful negative responsive distress to the brand'. In this study avoidance types as identity, moral and experiential avoidance are significant. Identity avoidance happens when consumers evade brands they do not want to be related with. Similarly when companies act negligent it can reason ethical misgiving with its consumers, all these will lead to brand avoidance. Past research proposes that, in case of negative ideological, identity incongruence and unmet expectations of consumers' preoccupied perceptions and feelings concerning the brand that play a vital role in consumers' action-related assessments [13].

Consumers reject certain brands, not because of financial pressures, however, because of predominantly unmet expectations, ideological incapability and identity concerns. When consumers observe that the products and concerned brands are not distributing what have been assured, moreover because of brand misbehavior and not meeting expectations, due to symbolic incongruence and ideological incompatibility between themselves and the brand [14], the positive relationship among consumer and brand may turn into negative, wherever consumers merely not want to assistant themselves with those brands and ultimately discard to contain them into their own personalities. They definite their displeasure with the corporate behavior or products of a brand by either brand avoidance or in thrilling methods in anti-consumption or boycotting. It is revealed that in the case of negative experiential, moral, or identity evaluations consumers' assessments about the brand are essential in shaping their actions and emotions [13].

\section{Problem statement}

Development of branding has significant position in academe of marketing as well as implementation. Though numerous studies concentrated on the encouraging approaches as well as behaviors that customers contain to products, as economic environment of world changes rapidly. The business should also change, adjust and modify their business strategies according to changing situations and competition in external environment. Specially, the smartphone industry of Pakistan needs to develop and modify their product and business accordingly. The branding strategies are the important part of any marketing plan because it is one of the essential marketing tools to enhance the customer base. The marketers and manufacturers of smartphone should truly emphasis and focus on branding strategies and marketing campaign to make a strong brand and to achieve true customer loyalty and gain a higher market share in their industry.

Though, correspondingly effective is the indication which certain persons evade some goods plus products due to undesirable implications/suggestions [15-18]. However, pending newly [19], this emerging idea is prevailing and getting attention those customers refusing definite products to evade addition rejected implication. Therefore, the harmful features of products, as well as prospective to develop market-based responsibilities for the organization, these were not actually spoken by means of practice and academe of marketing. Therefore, there is a difficulty which means that this thesis purposes to address the increasing attention in anti-consumption. Concerned topic adds to anti-consumption study through sightseeing the occurrence of product evasion or brand avoidance. Previous researches examining that the evasion of brands contain basic information and deteriorating to version for the extensive series of causes and fundamental evasion of brand. Influence of brand evasion in case of smartphones was not studied.

Positive consumer behaviour and loyalty toward brands are quite widely explored topics in scientific community, however, the anticonsumption topic is poorly examined and could still be considered as a fresh subject to study [20-22]. It was only during the last decade that the topic of anti-consumption and one of its components - brand avoidance - attained more scientific attention [23-25]. Even though the interest in the topic is growing, there is still a lack of comprehensive understanding of anti-consumption and its motives.

Consequently, there are extensive recognized opinions about products that are frequently nominated for numerous encouraging implications and assistances signify to the customer. Though, It is also effective that certain persons evade certain goods due to equally valid is the idea that some people avoid certain products due to undesirable attachment and affiliations $[10,17,18$,$] . Moreover, the concept of brand$ avoidance is developing and not yet examined properly, focusing in only in the developing market of New Zealand as well as the USA [26,27].

However, in spite of all this increasing attention, the existing work and literature has shortages of complete consideration about anticonsumption which is connected to different themes. Additionally, the reputation of a sturdy brand ensures the customer with trust and in this sense help to attract new customer and retain the old customers too. People are connected to their phones whether they are at the airport, moving down the roads and street, sitting in a cafeteria or coffee shop or inside a shopping mall mostly individuals everywhere uses the cellphones or smartphones. Moreover businesses are also running through the smart phones via internet, email, messages, WhatsApp, Facebook and Skype etc. Apart from above facts, the trend which has been seen in smartphone users that people frequently switches their smartphone brand. This problem is nearly facing by all the smartphone companies prevailing in the country. Brand switching defines consumer switches from one brand to another brand to achieve the satisfaction level which may lead to the brand avoidance which stimulate to the brand hate and people moving to negative brand equity. So now the goal of every company is to focus on the brand equity especially positive brand equity that will enhance the revenue of any smartphone brand.

Current study also possesses some demerits which seem to have restrictions towards preceding the anti-consumption performance. Explicitly, scholars of this study hardly have some queries about it. Why, certain customers endure to buy some products regardless of the plainly adverse insolences to the product or brand. A connected constraint of previous scholarships are they did not investigated in the obvious situations which would alter the opinion of the customers about the use of smartphones in relations to repeat purchase and evaded brand. Significance of understanding about issues can confine brand evasion that is apparently pertinent to the administration.

\section{Significance and gap analysis}

This study is significant acceding to practical and theoretical perspective. It bestow researcher and literature a new framework 
to investigate the impact of brand related motives on brand equity and will assist them in better understanding the association among dependent variable brand equity and independent variable i.e., Brand avoidance motivators or brand related motives. Literature was not available brand avoidance which has empirically studied the relation between independent and dependent variables i.e., brand related motives and brand equity. likewise, no study has been found which has been studied the mediating impact of brand hate between independent and dependent variables i.e., brand related motives and brand equity.

The literature and research of brand avoidance is still rare, as most of the research is being qualitative and frequently investigating only singular brand avoidance motives [7]. It is determine that unsolicited consumer behavior (including brand avoidance) which can be activated by consumers have experience of negative emotions toward brands [28]. Though, there is a deficiency of research on brand avoidance, it is still not vibrant that how brand hate is connected with brand avoidance. Besides, brand avoidance has not been examined in developing markets yet, concentrating instead only on such markets as New Zealand [21].

Consequently, in order to obtain an improved understanding of how brand avoidance seems, the objective of this paper is to identify what associations be between numerous brand-related stimuli, to define the modification in brand equity because of variance in brand related motives. The key outcome of this work is the extended information about this yet poorly studied but very stimulating topic, which is only preliminary to acquire more consideration from marketing scholars. Different survey presented that people try to avoid brands and they do feel numerous negative feelings towards brands, though, these feelings are not equally strong. Also, despite the expectations based on the theoretical background, the survey results showed that no associations exist among all of the different brand-related motives, brand hate and various brand equity, as well as between all of various negative feelings and intention to avoid brands.

Smartphone industry of Pakistan is very competitive in nature. All the companies are providing different types of smartphone models which are based on different features. This thing is leading the customers to switch the brand. This switching behavior makes the customer less loyal. Working on unmet expectations, Symbolic incongruence and Ideological incompatibility according to customer needs and requirements create the chance for companies to make customers loyal and actively engaged to the particular brand so this study will be helpful in better consideration of the consumer response in perspective of consumer brand involvement.

\section{Research questions}

To discourse the restrictions of earlier researches in the extent of product evasion as well as study of extensive literature identifies the following questions that need to be empirically answered.

Following are the research questions of this research:

Question1: How Unmet Expectation stimulates the brand equity?

Question 2: How Symbolic incongruence stimulates the brand equity?

Question 3: How Ideological incompatibility stimulates the brand equity?

Question 4: How does brand hate mediates the relationship between Unmet Expectations and brand equity?
Question 5: How does brand hate mediates the relationship between Symbolic incongruence and brand equity? Question 6: How does brand hate mediates the relationship between Ideological incompatibility and brand equity?

\section{Research objectives}

Recognizing the difficulties in researches and academe this topic has several objectives. Existing research explores the relation between brand avoidance motivators and brand equity. However, three specific objectives are given below.

- To determine the effect of Unmet Expectations on brand equity.

- To determine the effect of Symbolic incongruence on brand equity.

- To examine the effect of Ideological incompatibility on brand equity.

- To determine the mediating role of brand hate between Unmet Expectations and brand equity.

- To find out the mediating role of brand hate between Symbolic incongruence and brand equity.

- To examine the mediating role of brand hate between Ideological incompatibility and brand equity.

\section{Literature Review}

\section{Band equity}

Brand equity is familiar as the furthermost marketing idea with respect together the perspective of practice and academic. Academia wants to understand and clarify that how can be a brand equity being measured and how important for any firm while, practitioners want to recognize that how brand equity can be increases and how it influence the consumer decisions with respect to different brand buying. The term Brand equity was introduce during late 1980s, the status of theorizing, evaluating and determining brand equity has developed speedily both for academics and practitioners [29,30]. It may be stemmed in "several often-divergent views on the scopes of brand equity, Different features are there which influence it, the viewpoints which should be considered, and the methods to determine it" [31]. Some diverse descriptions and approaches to determine the brand equity have been expected from them some are based on Farquhar's [32] definition: "it is an additional value that provide bestows to a product". Brand equity is vital subject of companies dealing with business, in spite of all this can be utilized by vendors and stakeholders to obtain competitive edge through effective brands.

Any brand that undergo from continued periods of brand avoidance or deteriorating consumer relations may develop negative brand equity, so in result the customers constantly respond unfavorably to these brand [3]. Stated that it keep adverse system of equity as awareness and behaviors of distributors, retailers, along this channel members or market place general, intermingle to create an unfavorable impression of a brand. The company' efficiency and effectiveness in the market drops due to avoided brand so the brand considered as a market-based liability, for the reason that it is truly a disadvantage for the business to own such brand.

Pitta and Katsanis [33] suggest that brand equity increase the relation between different brands which may lead to brand love and 
satisfaction protect the brand from going in competitive threats. Brand equity defined by Keller [3], the consequence of the brand on the consumer's response to the marketing actions related with some product. Mostly resilient brand generally offer greater profit margins and superior access to supply channels along with extensive stage for line extensions of different products [34]. Consequently, these and other models have been verified in a diversity of backgrounds.

Aaker and Equity [34] contributed to develop or constructed a brand e scale founded on the customers. Aaker's and Keller's model [35], devoted mainly on loyalty, perceived quality, brand associations well as awareness. Obviously any brand represents a distinction device which gives suggestions to customers through decision making procedure. An altered model of brand equity was proposed that was founded on Keller's [3] also it has underscored on binary parts of brand equity; one of them is brand awareness while other is brand image. First part is awareness that is based on promotion plus word of mouth whereas the second part is image which is shaped through the representative characteristics as social image, brand personality, putting brand in the targeted market place, according to characteristics of are supposed quality, price, services provided after sales, advantages obtained by utilizing the package and suggest characteristics as association among management and worker, place of the examination institute.

\section{Brand avoidance motivators}

Brand avoidance is a specific kind of anti-consumption and it can be happen when customers reject particular brands because it could add or enhance unwanted meaning to their life [19] reveals in study why buyers may avoid some brands even when they can easily afford them. When customers utilizing a service or products, he/she might mark a difference amid performance and prospects the service or any product [36]. Literature designated three forms of brand avoidance which are experiential, moral and identity brand avoidance [20]. Experiential avoidance may occur when buyer expectations were failed to meet what he expected. Identity avoidance could happen when brands are symbolically mismatched with the identity of the buyer. The consumers morally avoid a brand when he thinks that a brand's management policies have a negative consequence on society.

Conventionally consumer research emphases on scrutinizing the aspects which stimulate individuals to consume particular products or brands while, in order to have an intense understanding of consumers and their behavior it is in the same way important to recognize and understand what encourages them to choose not to consume or utilize [37]. Lee et al. [7] propose that brand avoidance behavior show when users observe some brand commitments to be mismatched with their wants or needs. Though, consumers can respond not only to what brands have promised but also to what they morally should have promised but in truth did not; consequently, brand avoidance behavior may not always be associated to what a brand is promising [38]. Brand rejection behaviors appear when negative attitudes, beliefs and emotions toward that brand develop strong and act as barricades to buying, No matter what a brand is (not) promising $[39,40]$. Furthermore, negative emotions toward a brand doesn't depend only after the purchase but can also be formed in advance so consumer may choose to avoid certain band [39]. The negative emotions toward brands can have direct relationship with brand avoidance behavior $[28,40]$. The negative emotions of customers towards a brand can provoke by different stimuli.

The central concept of anti-consumption concentrating against consumption, and it is not only an overall decrease of consumption or non-consumption, but it can be beleaguered towards particular products or brands too [25]. Nevertheless, anti-consumption does not essentially mean that people would entirely discontinue using particular products or services; it also includes reclamation, rejection and restriction of consumption [23]. Anti-consumption has been studied from many several perspectives and can take a lot of numerous kinds [25], like rejects ethical consumption brand avoidance [38], voluntary simplification, brand rejection [22], consumer resistance, anti-branding, sharing, anti-consumption inspired by means of undesired image congruence and self [41]. Firstly deliver a suitable and proper description of brand avoidance as "all events during which customers intentionally discard or select a brand". Brand avoidance emphases on the anti-choice, which is based on active refusal of a brand, not on the no choice occurrences when customers have no choice and are not able to buy brands because of unaffordability, inaccessibility or unavailability [10].

\section{Development of Hypothesis}

\section{Unmet expectations and brand equity}

Current studies proved the existence of unmet expectations as a significant factor for the behavioral intent of brand avoidance [42] and even recommended that negative preceding experiences are the most imperative in anti-consumption behavior [39]. According to Winchester and Romaniuk [43] the relationship between negative brand beliefs and purchase behavior presented that negative opinions about the brand are usually formed not previous to the purchase but after the purchase. Consequently, previous customers of the brand are further expected to have negative beliefs than existing customers or those who have not ever use the brand.

Brand hate can be bases on the negative experiences with certain product. Moreover, Lee et al. [20] found that dissatisfaction happen due to negative brand experience, which leads to brand avoidance. In brief, when customer expectations were failed to meet it leads to brand avoidance. Brand avoidance can happen due to product failure, level of service provided, poor performance, and unpleasant store environment.

H1: Unmet expectations has a significant negative effect on brand equity

\section{Symbolic incongruence and brand equity}

The other cause of encouraging consumers to avoid brands can be symbolic incongruence (undesired self). Consumers reject or refuse products and services due to their negative symbolic characteristics [44]. Thus, symbolic incongruence between brand and buyer can also be a cause for avoidance behavior. Consumers can craft their selfconcepts and self-identities not only through consumption of products and brands having positive symbolic values but also by rejecting and avoiding the ones having negative symbolic senses [45]. Furthermore, there are individuals who express their self-identities by using products or brands that suit their identity, while others to express themselves by avoiding products or brand which can damage their self-worth [44].

Other reason could be motivating consumers to avoid brands can be an undesirable cost to benefit trade-off, which can seem in diverse ways. Shown that some persons evade economical brands as they think that it is not worth paying money for low quality; while there are buyers who agree not to buy superior brands because they think that they are paying individual for a brand name which enhances no worth. Brand unfamiliarity can also be perceived as an objectionable trade- 
off because a customer might perceive an unfamiliar brand to have a higher risk related with the acquisition. Likewise, some individuals evaluate the value and quality of brands founded on their appearance, and if brand characteristics such as design or packaging are perceived as unappealing, aesthetic inadequacy will be perceived as undesirable trade-off [39].

People avoid brands that do not contest their identity, or when a brand is thoroughly connected to certain groups, identity avoidance can happen. People do not want to go to a certain group when that group is related with a particular brand. Additionally, some customers want to be perceived as an individual, so they avoid mainstream brands. Identity avoidance is related to the undesired-self and misidentification. Consumers will engage in brand evasion because as do not like to be realized a product which they consider that it contains negative brand rationalities or principles. Customers do not purchase products exclusively due to their functional benefits but also due to their symbolic meanings.

$\mathrm{H} 2$ : Symbolic incongruence has a significant negative effect on brand equity.

\section{Ideological incompatibility and brand equity}

Moral brand avoidance customers emphasis on social needs rather than individual, repel to the forces which have negative influence on society and believe that they have to evade certain brands because it is the right thing to do. The chief reason for brand avoidance concerning social and moral concerns is the ideological unsuitability between a brand and customer, which can be distributed into two sub-themes: country of origin effects and anti-hegemony.

Avoiding a brand due to philosophical reasons, like political reasons, is motivated by moral avoidance [20]. A particular form of moral avoidance is the country of origin effects. Country of origin effects covers the surroundings in which products are manufactured, the environment where the company manufactures, and how the company behaves its employees. The greatest important elements of ethical avoidance are repelling dictating forces, a societal emphasis outside the individual, and have faith in that it is morally recognized to avoid some brands.

Dissatisfied customers due to failure of product or negative experience with a brand can develop hatred against that product. Research presented that experiential avoidance is the sturdiest motivator for brand hate, while identity avoidance was originate to be the weakest motivator for brand hate. Research is not clear about moral avoidance and its consequences, while numerous studies have examined moral avoidance and found different outcomes. Bryson et al. [12] create no evidence that moral avoidance can lead to brand hate, while other studies did found evidence that moral avoidance can certainly lead to brand hate [46].

H3: Ideological incompatibility has a significant negative effect on brand equity

\section{Brand hate as mediator}

In contrast to the concept of love, the concept of hate received less attention in the literature up to now. According to Rempel and Burris [47], the prevailing literature can be distributed in three different categories like psychoanalysis (interpersonal/familial context), social psychology (intergroup/hate crimes), and basic emotion research. Within these categories, there are inconsistent definitions of the notion of hate. Some denote to hate as a motivation [47] or emotion while others refer to hate as an attitude. Due to these inconsistencies, there is not yet a common definition of the concept of hate used in the literature. Most authors seem to agree that, in contrast of the above definition of emotion, hate is seen as a stable, continuing and a lasting feeling [48].

The triangular theory of love is used into the triangular theory of hate [49]. Sternberg [49] argues that 'hate contain many constituents which can be noticeable in diverse means also in diverse events'. Hence, he proposed a theory with three hate dimensions like disgust, anger, and deflation. Zeki and Romaya [50] on the basis of this theory developed the passionate hate scale to test whether ones subjective mental state towards an individual show particular arrays in the brain. They argue that hate is a multifaceted biological sentiment which has encouraged individuals to evil deeds. However, this theory explicates hate between people or groups and not the relationship between individuals and brands.

While brand love emphases on the association between customers and brands, brand hate derives of negative emotional affect towards the brand. Brand hate and brand avoidance have both been knotted to the meaning of intentionally avoiding or refusing a brand, yet only brand hate has been related to display behaviors like articulation negative feelings, refusing, or damaging company property. Likewise Bryson et al. [12] entitle that brand hate is like the exciting undesirable emotional component of assertiveness to a brand.

H4: Brand hate mediates the relationship between unmet expectations and brand equity.

H5: Brand hate mediates the relationship between symbolic congruence and brand equity.

H6: Brand hate mediates the relationship between Ideological incompatibility and brand equity

\section{Theoretical Support}

\section{Grounded theory}

Grounded theory is a procedural method working on the mentioned thesis to discover the sensation of product or brand evasion. It was established by Strauss and Glaser and in 1960s, grounded theory is a practice profoundly inclined through representative interactionism, like Strauss qualified with Blumer. It is an approach that permits the scholar to "search" that what is essentially "moving" in a singularity, and to "produce a philosophy from statistics". Meanwhile key purposes of mentioned thesis are to "determine" why customers evade brands, besides this how to progress a developing philosophy of product evasion, it is measured as a suitable practice (Figure 1).

\section{Methodology}

Key purpose of research is to study the effect of brand avoidance motivators (unmet expectations, symbolic congruence and Ideological incompatibility) on brand equity with mediating role of brand hate. This study is quantitative in nature. This study tries to examine the above mentioned relationship quantitatively. This study uses the hypothetic-deductive approach and a hypothesis is developed from which can be presumed certain observable and explicit predictions. As it uses data collection analysis of data in order to certify the proposed hypothesis and therefore on basis of it abstract conclusion. The type of study is causal. As it examines the cause and effect relationship between different variables. It pursues to predict change in dependent variable with the changes in independent variable. For sampling purpose 


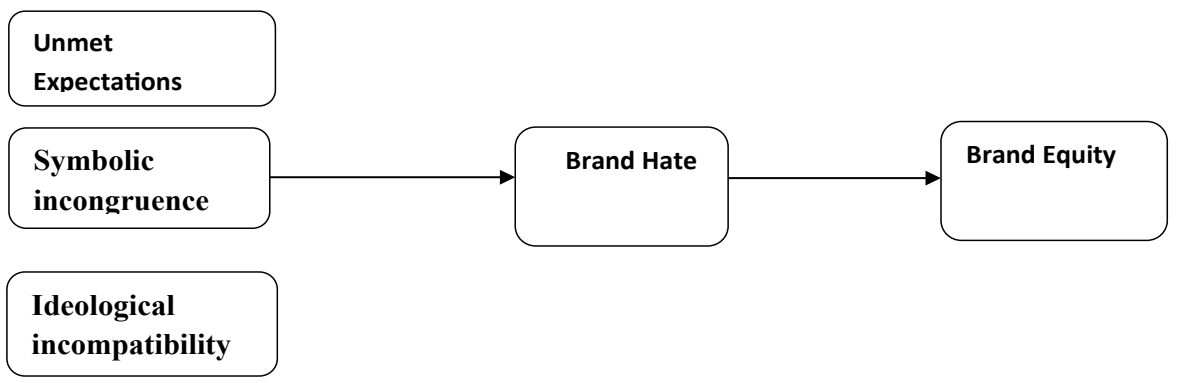

Figure 1: Theoretical framework.

procedure of non-probability convenience sampling technique was applied. The reason behind using this technique is the un-availability of list of total Smartphone users in Pakistan. That is why mobile phone users of Islamabad and Rawalpindi were selected as unit of study for analysis of this research. The selection of Islamabad and Rawalpindi was made to explore cultural heterogeneity and a little effort to increase the geographic generalizability of this study. Procedure of non-probability convenience sampling technique was used for the purpose of data collection. Self-administrative questionnaire was used for the collection of primary data for respondents of Islamabad and Rawalpindi.

Total 400 questionnaires were distributed in house wives, students, business owner and job holders living in Rawalpindi and Islamabad. 392 were received back from which 50 questionnaires were removed due to lack of desired response. After the removal of useless questionnaires a sample size of 270 yielded response rate up to $67 \%$. Sample size of 270 respondents was considered to cover the population of mobile phone users. Randomly 400 questionnaires were distributed in Rawalpindi and Islamabad.

Data were collected by provided well-organized questionnaires to Smart phone users of Rawalpindi and Islamabad. Respondents consisted of four categories (house wives, students, job holders and business men). Necessary information related to the topic of research work and general information of researcher was also mentioned in questionnaire.

\section{Data analysis}

The questionnaires entered in the statistical software after getting the responses from the respondents. The Cronbach's alpha is used to check the reliability of the questionnaire.

\section{Reliability}

A variable which has value equal or more than 0.50 is said to be reliable and it a good sign of reliability in the study. The reliability statistic is showing the value of variables of brand equity, unmet expectation, symbolic incongruence, ideological incompatibility and brand hate. All reliability variables have more than 0.5 reliability than it said to be as reliable.

\section{Factor loading}

The main purpose of the factor loading to find out the important dimension in the study. It also contains the degree in which items are important to measure the variable. This test is applied when you have large number of dimension. It confirms that the instrument is logically connected with the theory.

\section{KMO and Bartlett's test}

Kaiser-Meyer-Olkin test is used to check the adequacy of sample. It is an index which is used to analyze the appropriate of the factor analysis. The value of KMO lies in between the 0.5 to 1 than the factor analysis is suitable. The value of KMO is 0.9 . KMO measuring sampling adequacy is 0.90 which lies in between the 0.5 to 1 value. Therefore, construct validity of factor analysis is suitable. Barlett's gives the information about the suitability of the factor loading. This also provides the information about the hypothesis in which factor an uncorrelated with the variable (Table 1).

\section{Total variance explained}

The total amount of variance is analyzed in variable which is representing by each selected factor. It provides the large correlation explain by the small variation and small correlation explain the large variable. Table 2 is showing the total amount of variation in the dimension.

Normality tests are the distribution of balanced. Normality test provide the information weather the data are well modeled by a normal solution. The normality test can be tested through graphical test and numerical test. The graphical test includes:

Histogram with normal curve: Histogram curve is showing the representation of frequency distribution with the help of rectangles where width is showing the class interval and areas is showing the corresponding frequencies.

Autocorrelation: Durbin-Watson is used in Autocorrelation. The value of Durbin-Watson value is showing in the Table 2. The DurbinWatson value in the table is 1.714 . The acceptable range of the DurbinWaatson test is 1.6-2.4 or 1.8 -2.2. The value of Durbin-Waatson in this table is lies in between the ranges. Hence, it shows the normality of the data

\section{Multicollinearity}

The multicolineary issue can be assessed with the help of tolerance value. The tolerance value ranges from 0 to 1 . If the value of tolerance is less than or greater than then there will be the problem of multicollinearity exists. There are three variables are given in Table 3. The tolerance value of unmet expectation, symbolic incongruence and ideological incompatibility is in between the 0 to 1 . There is no issue of multiconearity in the data.

\section{Regression}

Model fit: The model summary (Table 4) is showing the value of $\mathrm{R}, \mathrm{R}$ Square, and adjusted $\mathrm{R}$ square and standard error of the estimate. $\mathrm{R}$ is showing the correlation between the ideological incompatibility, 


\begin{tabular}{|c|c|c|c|c|c|c|c|}
\hline \multirow{2}{*}{\multicolumn{4}{|c|}{$\begin{array}{l}\text { Kaiser-Meyer-Olkin measure of } \\
\text { sampling adequacy }\end{array}$}} & \multicolumn{4}{|c|}{ Bartlett's test of sphericity } \\
\hline & & & & \multicolumn{2}{|r|}{ Approx. chi-square } & \multirow{2}{*}{$\begin{array}{c}\text { Df } \\
741\end{array}$} & \multirow{2}{*}{$\begin{array}{c}\text { Sig } \\
0.000\end{array}$} \\
\hline \multicolumn{4}{|c|}{0.90} & & 5282.160 .598 & & \\
\hline \multicolumn{8}{|c|}{ Table 1: KMO and Bartlett's test. } \\
\hline Model & $\mathbf{R}$ & $\begin{array}{c}\mathbf{R} \\
\text { square }\end{array}$ & $\begin{array}{r}\text { Adjust } \\
\text { squa }\end{array}$ & & $\begin{array}{l}\text { Std. error of the } \\
\text { estimate }\end{array}$ & & $\begin{array}{l}\text { urbin- } \\
\text { Vatson }\end{array}$ \\
\hline 1 & $0.290^{\mathrm{a}}$ & 0.084 & 0.07 & & 0.43237 & & 1.71 \\
\hline
\end{tabular}

Table 2: Model summary for variation.

\begin{tabular}{|l|c|c|}
\hline \multirow{2}{*}{ Variables } & \multicolumn{2}{|c|}{ Collinearity statistics } \\
\cline { 2 - 3 } & Tolerance & VIF \\
\hline Unmet expectation & 0.697 & 1.436 \\
\hline Symbolic incongruence & 0.557 & 1.796 \\
\hline Ideological incompatibility & 0.713 & 1.402 \\
\hline
\end{tabular}

Table 3: Multicollinearity.

\begin{tabular}{|c|c|c|c|c|c|}
\hline Model & $\mathbf{R}$ & $\begin{array}{c}\mathbf{R} \\
\text { square }\end{array}$ & $\begin{array}{c}\text { Adjusted R } \\
\text { square }\end{array}$ & $\begin{array}{c}\text { Std. error of } \\
\text { the estimate }\end{array}$ & $\begin{array}{c}\text { Durbin- } \\
\text { Watson }\end{array}$ \\
\hline 1 & $0.694^{\mathrm{a}}$ & 0.482 & 0.476 & 0.41704 & 1.710 \\
\hline
\end{tabular}

Table 4: Model summary for regression.

\begin{tabular}{|c|c|c|c|c|c|c|}
\hline \multicolumn{2}{|c|}{ Model } & Sum of squares & df & Mean square & F & Sig. \\
\hline \multirow{2}{*}{1} & Regression & 43.009 & 3 & 14.336 & 82.431 & $0.000^{\mathrm{b}}$ \\
\cline { 2 - 7 } & Residual & 46.263 & 266 & 0.174 & & \\
\hline & Total & 89.272 & 269 & & & \\
\hline
\end{tabular}

Table 5: ANOVA.

symbolic incongruence and unmet expectation. The $\mathrm{R}$ Square is also called the coefficient of determination. The $\mathrm{R}$ square representing the value is 0.482 . The ideological incompatibility, symbolic incongruence, unmet expectation are explaining the $48.20 \% \%$ variation in brand quality.

\section{Statistical significance}

ANOVA tests: Analysis of variance test is used to check the combined effect of independent variables on dependent variable. ANOVA is the statistical method in which yield value can test to find the existence of significant relationship between the variables. The ANOVA model contains the variance analysis between the brand equity and ideological incompatibility, symbolic incongruence and unmet expectation. The independent variables are statistically predicting the dependent variable. The regression model is good fit for the data. The probability value is showing 0.0 which is less than 0.05 . Hence, it shows that there is valid model (Table 5).

\section{Estimated model coefficients}

The coefficient table is showing the value of unstandardized coefficient, standardized coefficient and $\mathrm{P}$ values. The Unmet expectation has its $\beta$ values equal to 0.325 . There is positive relationship between the unmet expectation and brand equity. It means that one unit increase in unmet expectation, brand equity will increased by 0.325 units. The symbolic incongruence is showing it $\beta$ equals to 0.216 . There is positive relationship between the symbolic incongruence and brand equity. One unit increase in symbolic incongruence, brand equity will increase by 0.0216 units. The $\beta$ value is 0.165 . There is positive relationship between ideological incompatibility and brand equity. One unit increase in ideological incompatibility there will be increase of 0.165 unit brand equity.

In Table 6 significance column is showing the significant value of

\begin{tabular}{|c|c|c|c|c|c|c|}
\hline \multicolumn{2}{|c|}{ Model } & \multicolumn{2}{|c|}{$\begin{array}{c}\text { Unstandardized } \\
\text { coefficients }\end{array}$} & $\begin{array}{c}\text { Standardized } \\
\text { coefficients }\end{array}$ & t & \multirow{2}{*}{ Sig. } \\
\cline { 2 - 6 } & B & Std. error & Beta & & \\
\hline \multirow{2}{*}{1} & Unmet expectation & 0.325 & 0.043 & 0.401 & 7.579 & 0.000 \\
\cline { 2 - 6 } & $\begin{array}{c}\text { Symbolic } \\
\text { incongruence }\end{array}$ & 0.216 & 0.051 & 0.248 & 4.187 & 0.000 \\
\cline { 2 - 6 } & $\begin{array}{c}\text { Ideological } \\
\text { incompatibility }\end{array}$ & 0.165 & 0.042 & 0.206 & 3.941 & 0.000 \\
\hline
\end{tabular}

Table 6: Coefficients.

the variables. The standard value of $\alpha$ is 0.05 . The $P$ value of unmet expectation is 0.00 which is less than 0.05 . It accepts the hypothesis. Unmet expectation has a significant negative effect on brand equity. The $\mathrm{P}$-value of symbolic incongruence is 0.000 . This value is less than 0.05 . It means that symbolic incongruence has significant negative effect on brand equity. It accepts the hypothesis. The ideological incompatibility is showing its probability value equals to 0.00 . This is less than 0.05 . It means that ideological incompatibility has a significant negative effect on brand equity. It accepts the hypothesis.

\section{Mediation}

The below mediation effect on the basis of Andrew F. Hayes. The $\mathrm{Y}$ is representing the brand equity which is dependent variable. Unmet expectation is independent variable and brand hate is mediating variable. The model summary is showing that there is significant relationship between the brand equity, unmet expectation and brand hate. The unmet expectation significant predicator brand hate in model summary. Brand hate and unmet expectation is significant predictor of brand equity as its value is 0.00 . Unmet expectation and brand hate is significant predictor of brand equity as the value is less than 0.05 . Unmet expectation significant predicts the brand equity as shown in the total direct effect table. The indirect effect of unmet expectation on brand equity is significantly less than 0.05 . It accepts the hypothesis. The $\mathrm{Y}$ is representing the brand equity which is dependent variable. Symbolic congruence is independent variable and brand hate is mediating variable. The model summary is showing that there is significant relationship between the brand equity, symbolic congruence and brand hate. The symbolic congruence significant predicator brand hate in model summary. Brand hate and unmet expectation is significant predictor of brand equity as its value is 0.00 . Symbolic congruence and brand hate is also not significant predictor of brand equity as the value is greater than 0.05 . Symbolic congruence is significant predicts the brand equity as shown in the total direct effect table. The indirect effect of symbolic congruence on brand equity is significantly less than 0.05 . Hence, it accepts the hypothesis.

The below mediation effect on the basis of Andrew Hayes. The Y is representing the brand equity which is dependent variable. Ideological incompatibility is independent variable and brand hate is mediating variable. The model summary is showing that there is significant relationship between the brand equity, ideological incompatibility and brand hate. The ideological incompatibility significant predicator brand hate in model summary. Brand hate and Ideological incompatibility is also significant predictor of brand equity as its value is less than 0.05 . Ideological incompatibility and brand hate is significant predictor of brand equity as the value is less than 0.05 . Unmet expectation significant predicts the brand equity as shown in the total direct effect table. The indirect effect of ideological incompatibility on brand equity is significantly less than 0.05 . It accepts the hypothesis.

\section{Discussion}

The success of brand is very important for the success of any 
business. The brand equity dependents upon the meeting the expectation of the customer. The brand is playing the symbolic impact on the brand equity. Brand equity plays a vital role in the smartphone industry of Pakistan. Positive rated brand are very important to gain the competitive advantage. The consumer behavior research focus on the positive perspective of the brands. The negative brand relationship can damage to company which owns the brand [8]. The consumer may not discontinue use of definite brand. The consumer feedback is crucial for the success of the organization.

The current study is showing that unmet expectation has a significant negative effect on brand equity. The study of Winchester research on negative brand belief and purchase behavior not prior to purchase but after it. The basic evidence is that consumers are employing in the brand avoidance because they don't want to be related with the brand which perceive be negative in the value meanings [21]. If the brand does not meet the requirement of customer it will affect the brand equity.

The study is showing that brand incongruence has a significant effect on the brand equity. Brand incongruence is the second reason to avoid the brand equity. This can be the reason for avoidance of behavior. The consumer may reject the products because of negative symbolic attributes of the product [44]. The consumer may create the self-meaning to avoid or rejecting the brand once it become the negative symbolic meaning. Consumers can create their self-identities and selfconcepts not only through consumption of products and brands having positive symbolic values but also by rejecting and avoiding the ones having negative symbolic meanings [15]. The study has confirmed that ideological incompatibility has a significant negative effect on the brand equity. Ideological incompatibility motivates the brand avoidance. This is the systematic ideas which are organized in a particular way. The broader aspect of ideology can under be understand as the part of consumption and marketing based on the free market economy [51]. It is necessary that there should be ideological compatibility to avoid the negative effect on brand equity.

The study also confirmed that brand hate the mediate the relationship between the unmet expectation and brand equity. It changes the perception of the consumer toward the brand. The brand equity is the building connection with consumer through experience. It is necessary for the organization to meet the expectation of the consumer to reduce to the brand hate which ultimately increases the brand equity. Consumer like the good brand. If it does not fulfill the requirement it reduces the satisfaction level of the consumer which ultimately impact on the brand equity. This motivation is often caused by the gap between the expectations one has about the product and the actual performance of the product [21].

The study has also shown the brand hate is predicting the relationship between the symbolic congruence and brand equity. It provides the insignificant results of the study. It means that if the brand hate will be high it does impact on the symbolic congruence brand equity. The brand equity is does not get the effect because of brand hates.

It is given in the empirical study that brand hate mediates the relationship between the ideological incompatibility and brand equity. The brand hate effect the ideological incompatibility to compatibility of the brand which ultimately impact on the reputation of the product. It will increase in the brand equity. It is necessary for organization to stop the brand avoided behavior in order to minimize the negativity about the brand. Organization should also not create the situation which creates the brand avoidance behavior for the consumers. It causes the negative attitude of the consumer [38].

\section{Conclusion}

Unhappy consumers are greatest source of knowledge for both practitioners and academics. Unluckily mostly it was ignored because generally conventional brand management emphases on selection of brand, loyalty of brand as well as preferences of consumers. This thesis of brand avoidance motivators discourses the difference in research through reconnoitering the causes why brands are evaded by some people. Definitely, one wide-ranging impact of this is to deal with an innovative viewpoint to observe the attitude of consumers and brand management.

By means of grounded theory approach and distribution of questionnaire, quantitative data were collected to support clarify two areas of concern first is motivators of brand avoidance and second is the brand equity. Motivators of brand avoidance emerged and three foremost categories 'experiential', 'identity', and 'moral avoidance' were discussed. Contributors evaded numerous brands and products due to 'not meeting requirements, metaphorically unappealing' as well as 'communally detrimental' assurances signified by brand or products to consumers.

This research work set out to identify how motivators of brand avoidance works or cause changes in brand equity with presence of brand hate. In Pakistan, there is held a tough competition between the Smartphone companies, having the large customer base. The consumers of these smartphone companies usually seek benefits in order to purchase a phone under same brand. Due to the availability of many smartphones brand enhance the opportunity for any customer to switch their smartphone brand if he or she doesn't receive the desired benefits. As tough competition is prevailing in the market, the companies need to reach a point where they can get sustainable competitive advantage in order to make the customer loyal and enhance the positive brand equity instead of negative that may lead to spoil the image of the brand. It is concluded that the consumers start to hate from phone if that phone did not meet their expectations, symbolic congruence and ideological incompatibility which added in brand avoidance. Motivators of brand avoidance like unmet expectations, symbolic congruence and ideological incompatibility are the basic motivators due to which customer search for any other smart phone brand. It is proved from the research that people avoided from smartphone brands by keeping in view the brand avoidance motivators.

The smartphone which is not fulfilling the unmet expectations, symbolic congruence and ideological incompatibility and not performing function according to requirements of customers led them towards brand hate which is a strong and link to negative brand equity. Generally, research discourses all of its studied questions and attains all of its ideas. This also delivers a substantial plus specific theoretical impact by means of offering a comprehensive, integrative and innovative knowledge of brand avoidance. In spite of all, this thesis also provides a valued supervisory support by means of proving a strong rationale and much stable viewpoint about brand management of smartphones. This thesis delivers valued answers to the important questions of brand avoidance.

\section{Implications for Managers and Marketers}

For marketing implications, I should determine that what the reasons due to which customers are changes their attitude towards brand avoidance and keeps tactics to pact about brand avoidance. 
Such practice can be assumed profitable for the other company which has satisfied customers and consumers. Hence, this research creates a significant input in marketing through accumulative level of understanding as well as amount of knowledge in the area of brand avoidance.

Results obtained from this study are cooperative and helpful for managers, marketers as well as vendors. This study will prove beneficial for the literature. Besides this numerous influencers of this study also have significant consequences. The smartphone industry of Pakistan is rapidly growing with passage of time. There are many competitive smartphone brands which are competing with each other on several bases. The trend of using smartphone brand among people of Pakistan has also been increasing. Reason of this trend is availability of $3 \mathrm{G}$ and $4 \mathrm{G}$ in almost every city of Pakistan. In such tough competition marketers needs to focus on different effective strategies which can significantly enhance the sustainable competitive advantage and help to facilitate their customers. Mangers and marketers should focus on the dimensions of the brand avoidance and develop some strategies that can minimize the trend of brand avoidance.

This study illustrates that every brand and every product category has brand hate. Thus it is necessary for marketers and mangers to avoid the brand avoidance motivators. Unmet expectations is the utmost risky source of brand hate, subsequently it can clue to all of the dynamic behaviors. This motivator is frequently initiated by means of the gap among the expectations consumers possesses for the performance of the product [21]. Though, this motivator can be surely prohibited by companies. The reasonable stage is to continually achieve the quality of the services as well as product and to retain the delivered promises. Besides this firms required to permit consumers to grumble openly to the firm before the arousal of problem. Brand hate is the outcome of accrued negative feelings. Second, marketing managers should continuously have thoughtfulness decision making for the targeting market groups. In other words the target groups and marketing plans show a vital role in the brand image of the product and it should be clearly attained. Lastly, the social corporate responsibility of the firms should also be clearly observed by the managers and continually has question the reliability of the activities. For developing new strategies management should encounter the ethical concerns.

\section{Limitations and Future Research Directions}

This research also contains some restrictions or limitations which can be focused by other researchers for the future research directions. The focus of this research was only on the smartphone industry. The research can also be protracted to the other industry like FMCGs, automobiles, electronics and restaurants etc. Along this, it should also conduct in some other areas of service industries. The longitudinal study can also be conducted in this area. The population that was considered in this research was comprised of university students, job holders, house wives and small business retailers. Enhancements in sample can be done in order to get more consistent results in Pakistani context. Experimentation technique can also be incorporated in the research model. The data obtained only from the twin city of Rawalpindi and Islamabad, it can be obtained from different cities of Pakistan in order to capture diversity and enhance generalizability. All motivators of brand avoidance can also be explore and sturdies in this model. The other variables that can be studies in this study like brand hate, emotions and motives of brand hate should.

\section{References}

1. Richins ML (1983) Negative word-of-mouth by dissatisfied consumers: A pilot study. The Journal of Marketing, pp: 68-78.
2. Srivastava RK, Shervani TA, Fahey L (1998) Market-based assets and shareholder value: A framework for analysis. The Journal of Marketing, pp: 2-18.

3. Keller KL (1993) Conceptualizing, measuring, and managing customer-based brand equity. The Journal of Marketing, pp: 1-22.

4. Berry LL (2000) Cultivating service brand equity. Journal of the Academy of Marketing Science 28: 128-137.

5. Christodoulides G, De Chernatony L (2010) Consumer-based brand equity conceptualization and measurement: A literature review. International Journal of Research in Marketing 52: 43-66

6. Luo X, Wiles M, Raithel S (2013) Make the most of a polarizing brand. Harvard Business Review.

7. Lee MS, Fernandez KV, Hyman MR (2009) Anti-consumption: An overview and research agenda. Journal of Business Research 62: 145-147.

8. Fournier S, Alvarez C (2013) Relating badly to brands.

9. Allsop DT, Bassett BR, Hoskins JA (2007) Word-of-mouth research: principles and applications. Journal of Advertising Research 47: 398-411.

10. Hogg MK, Michell PC (1997) Special session summary: Exploring anticonstellations: Content and consensus. Advances in Consumer Research 24 61-63.

11. Narayana CL, Markin RJ (1975) Consumer behavior and product performance: An alternative conceptualization. The Journal of Marketing, pp: 1-6.

12. Bryson D, Atwal G, Hultén P (2013) Towards the conceptualization of the antecedents of extreme negative affect towards luxury brands. Qualitative Market Research: An International Journal 16: 393-405.

13. Trump RK (2014) Connected consumers' responses to negative brand actions: The roles of transgression self-relevance and domain. Journal of Business Research 67: 1824-1830

14. Srivastava RK, Fahey L, Christensen HK (2001) The resource-based view and marketing: The role of market-based assets in gaining competitive advantage. Journal of Management 27: 777-802.

15. Banister EN, Hogg MK (2004) Negative symbolic consumption and consumers' drive for self-esteem: the case of the fashion industry. European Journal of Marketing 38: 850-868

16. Englis BG, Solomon MR (1997) Special Session Summary I am not Therefore I am: The role of avoidance products in shaping consumer behavior. NAAdvances in Consumer Research 24.

17. Levy SJ (1959) Symbols for sale. Harvard Business Review 37: 117-124.

18. Thompson CJ, Arsel Z (2004) The Starbucks brandscape and consumers (anticorporate) experiences of glocalization. Journal of Consumer Research 31 : 631-642.

19. Thompson CJ, Rindfleisch A, Arsel Z (2006) Emotional branding and the strategic value of the doppelgänger brand image. Journal of Marketing 70: 50-64.

20. Lee MS, Conroy D, Motion J (2009) Brand avoidance: a negative promises perspective. NA-Advances in Consumer Research 36.

21. Lee MS, Motion J, Conroy D (2009) Anti-consumption and brand avoidance. Journal of Business Research 62: 169-180

22. Truong $O$ (2011) The incidence of brand rejection in FMCG categories.

23. Lee MS, Cherrier H, Roux D, Cova B (2011) Anti-consumption and consumer resistance: Concepts, concerns, conflicts, and convergence. European Journal of Marketing 45: 11-12.

24. Kozinets RV, Handelman JM, Lee MS (2010) Don't read this; or, who cares what the hell anti-consumption is, anyways?. Consumption, Markets and Culture 13: 225-233.

25. Iyer R, Muncy JA (2009) Purpose and object of anti-consumption. Journal of Business Research 62: 160-168.

26. Hollenbeck CR, Zinkhan GM (2010) Anti-brand communities, negotiation of brand meaning, and the learning process: The case of Wal-Mart. Consumption, Markets and Culture 13: 325-345

27. Close AG, Zinkhan GM (2009) Market-resistance and Valentine's Day events. Journal of Business Research, 62: 200-207. 
Citation: Abid R, Khattak A (2017) Brand Avoidance Motivators Stimulate to Brand Equity in the Mediating Role of Brand Hate: A Case of Smartphone Industry of Pakistan. J Account Mark 6: 250. doi: 10.4172/2168-9601.1000250

28. Romani S, Grappi S, Dalli D (2012) Emotions that drive consumers away from brands: Measuring negative emotions toward brands and their behaviora effects. International Journal of Research in Marketing 29: 55-67.

29. Netemeyer RG, Krishnan B, Pullig C, Wang G, Yagci M, et al. (2004) Developing and validating measures of facets of customer-based brand equity. Journal of Business Research 57: 209-224.

30. Aaker DA, Equity MB (1991) Capitalizing on the value of a brand name. New York.

31. Ailawadi KL, Lehmann DR, Neslin SA (2003) Revenue premium as an outcome measure of brand equity. Journal of Marketing 67: 1-7.

32. Farquhar PH (1989) Managing brand equity. Marketing research 1.

33. Pitta DA, Prevel Katsanis $L$ (1995) Understanding brand equity for successfu brand extension. Journal of Consumer Marketing 12: 51-64.

34. Aaker DA, Equity MB (1991) Capitalizing on the Value of a Brand Name. New York.

35. Aaker DA, Keller KL (1990) Consumer evaluations of brand extensions. The Journal of Marketing, pp: 27-41.

36. Farquhar GD, Ehleringer JR, Hubick KT (1989) Carbon isotope discrimination and photosynthesis. Annual review of Plant Biology 40: 503-537.

37. Zavestoski S (2002) Guest editorial: Anticonsumption attitudes. Psychology and Marketing 19: 121-126.

38. Rindell A (2013) Time in corporate images: introducing image heritage and image-in-use. Qualitative Market Research: An International Journal 16: 197-213.

39. Nenycz-Thiel M, Romaniuk J (2011) The nature and incidence of private label rejection. Australasian Marketing Journal 19: 93-99.
40. Romani S, Grappi S, Dalli D (2008) I feel uneasy with this brand! consumers' negative emotions to brands and behavioral responses. In: Proceedings of the 1st International Consumption and Consumer Resistance Conference 28.

41. Sirgy MJ (1982) Self-concept in consumer behavior: A critical review. Journal of Consumer Research 9: 287-300.

42. Kim H, Jung Choo H, Yoon N (2013) The motivational drivers of fast fashion avoidance. Journal of Fashion Marketing and Management: An International Journal 17: 243-260.

43. Winchester M, Romaniuk J (2008) Negative brand beliefs and brand usage. International Journal of Market Research 50: 355-375

44. Hogg MK, Cox AJ, Keeling K (2000) The impact of self-monitoring on image congruence and product/brand evaluation. European Journal of Marketing 34 $641-667$.

45. Chatzidakis A, Lee MS (2013) Anti-consumption as the study of reasons against. Journal of Macromarketing 33: 190-203.

46. Delzen MV (2014) Identifying the motives and behaviors of brand hate (Master's thesis, University of Twente).

47. Rempel JK, Burris CT (2005) Let me count the ways: An integrative theory of love and hate. Personal Relationships 12: 297-313.

48. Weingarten K (2006) 'On hating to hate'. Family Process 45: 277-288.

49. Sternberg RJ (2003) A duplex theory of hate: Development and application to terrorism, massacres, and genocide. Review of General Psychology 7: 299.

50. Zeki S, Romaya JP (2008) Neural correlates of hate. PLoS ONE. 3: 3556.

51. Kozinets RV, Handelman JM (2004) Adversaries of consumption: Consumer movements, activism, and ideology. Journal of Consumer Research 3: 691-704. 